\title{
Comparative analysis of DNA methylation between primary and metastatic gastric carcinoma
}

\author{
JI HUN KIM ${ }^{1}$, EUN JI JUNG ${ }^{2}$, HYE SEUNG LEE ${ }^{3}$, MIN A. KIM $^{1}$ and WOO HO KIM ${ }^{1,2}$ \\ ${ }^{1}$ Department of Pathology, ${ }^{2}$ Cancer Research Institute, Seoul National University College of Medicine, Seoul 110-799; \\ ${ }^{3}$ Department of Pathology, Seoul National University Bundang Hospital, Gyeonggi 463-707, Republic of Korea
}

Received December 3, 2008; Accepted January 15, 2009

DOI: $10.3892 /$ or_00000348

\begin{abstract}
Metastasis is a multi-step process involving many biomolecular changes and DNA methylation is one such molecular change. Although differences in DNA methylation have been reported in matched primary and metastatic mammary carcinoma, no such differences have been reported in gastric carcinoma. Accordingly, to investigate whether DNA methylation profiles in metastatic gastric carcinoma differ from those of their primary counterparts, we investigated the DNA methylation of eleven genes, ADAM23, CDH1, FHIT, FLNC, GSTP1, ITGA4, LOX, RUNX3, THBS1, TIMP3, and UCHL1 in 74 matched human primary gastric carcinomas, lymph node metastases, non-neoplastic gastric mucosal, and uninvolved lymph node tissues by utilizing methylationspecific PCR. Seven of these genes (ADAM23, FLNC, ITGA4, $L O X, R U N X 3, T I M P 3$, and $U C H L 1)$ showed cancer-specific methylation, and three (CDHI, FHIT, and THBS1) showed cancer-unrelated methylation. GSTP1 was rarely methylated in any tissue type. Of the seven genes that showed cancerspecific methylation, FLNC was more frequently methylated in metastatic gastric carcinomas than in their primary counterparts $(p=0.004)$. In addition, the average number of methylated genes in metastatic tumors was greater than that in primary tumors $(\mathrm{p}=0.004)$. The high-methylation group (cases with three or more genes methylated in primary tumors) was found to contain more women $(\mathrm{p}=0.031)$ and diffuse type tumors by Lauren classification $(\mathrm{p}=0.022)$. DNA methylation profiles were not found to affect prognosis. We suggest that promoter methylation of FLNC may be involved in the lymph node metastasis of gastric carcinoma and that the DNA
\end{abstract}

Correspondence to: Dr Woo Ho Kim, Department of Pathology, Seoul National University College of Medicine, 28 Yeongeondong, Seoul 110-799, Republic of Korea

E-mail: woohokim@snu.ac.kr

Key words: stomach neoplasms, lymphatic metastasis, DNA methylation, polymerase chain reaction methylation statuses of metastatic tumors should be considered in node-positive gastric carcinoma.

\section{Introduction}

Metastasis is a multi-step process that involves the release of cells from a primary site, their invasion into adjacent connective tissues, transmigration across the basement membrane, intravasation, tumor emboli formation, extravasation, and establishment of new growth at target organs. To successfully perform these tasks, genes responsible for cellular attachment, apoptosis, drug metabolism and various signal transductions must undergo appropriate genetic or epigenetic changes (1-3).

It is generally accepted that the majority of cancers produce heterogeneous clones while they grow at primary sites due to their inherent genetic instabilities, and that clonal evolution eventually creates metastasis-competent clones (4). These metastasis-competent clones detach from their primary sites and disseminate systematically via lymphatic or vascular channels and attach in regional lymph nodes or distant sites. The metastatic deposits produced were initially believed to have the same molecular profiles as the primary tumors. However, this point of view has recently been challenged, because molecular alterations, such as, DNA methylation and protein expression differences have been demonstrated in primary and metastatic cancers (5-9).

DNA methylation is a type of epigenetic change, which is defined as a heritable change in gene expression not involving alterations in the nucleotide sequence. In human cancers, DNA methylation is detected as global hypomethylation or as hypermethylation of specific promoter $\mathrm{CpG}$ islands (10). In particular, the hypermethylation of specific promoter $\mathrm{CpG}$ islands often results in the silencing of important tumor suppressor genes, and thus, promotes the development and progression of human cancers. Differences in the DNA methylation profiles of primary and metastatic cancers have been reported in several studies on breast cancers $(5,6)$ and gastric cancers $(7)$. However, it has not been established whether the DNA methylation profiles of metastatic deposits differ from those of primary tumors.

Gastric cancer is the fourth most common cancer and the second leading cause of cancer-related death worldwide (11). Although gastric cancer is now being increasingly detected in its early stage due to the introduction of screening endoscopy 
in Korea and Japan, many gastric cancers are still detected when advanced. Furthermore, when detected in an advanced stage, prognosis largely depends on the presence of lymph node or distant metastases.

In gastric cancer, DNA methylation has been reported to occur mainly during the early stage of carcinogenesis (12) and to increase during multi-step carcinogenesis (13) or to affect even histologically normal mucosa (14). More recently, DNA methylation has been reported in an advanced stage disease and in associated lymph node metastases (15). Nevertheless, differences between the DNA methylation profiles of primary and metastatic gastric cancer have not been well documented.

To determine whether DNA methylation profiles are different between primary and metastatic gastric carcinomas, we investigated the promoter methylation of 11 putative tumor suppressor genes, namely, a disintegrin and metalloproteinase domain 23 preproprotein (ADAM23), cadherin-1 (CDH1), fragile histidine triad gene (FHIT), gamma-filamin (FLNC), glutathione S-transferase pi (GSTP1), integrin alpha 4 (ITGA4), lysyl oxidase (LOX), runt-related transcription factor 3 (RUNX3), thrombospondin 1 (THBS1), tissue inhibitor metalloproteinase 3 (TIMP3) and ubiquitin carboxylterminal esterase L1 (UCHL1) in 74 human gastric carcinomas and in matched lymph node metastases by methylationspecific PCR (MSP). These 11 genes were selected because it has been reported that their promoters are methylated and their respective target mRNAs are silenced in gastric carcinoma (16-21) and because some of them are known to be functionally related to metastasis, i.e., ADAM23, membrane adhesion and cell migration, $C D H 1$, cell adhesion, $F L N C$, organization of actin polymerization and cell motility, ITGA4, cell-extracellular matrix, cell-cell interactions, THBS1, angiogenesis, and TIMP3, extracellular matrix degradation. Corresponding non-neoplastic mucosa and uninvolved lymph node tissues were included for control purposes, because some genes are frequently methylated in chronic gastritis and intestinal metaplasia, and because methylation has also been associated with aging (14).

\section{Materials and methods}

Patients and samples. The files of surgically resected gastric cancer cases examined at the Department of Pathology, Seoul National University College of Medicine between January 1, 1996 and December 31, 1996 were initially included. Age, gender, tumor location, gross type (according to Borrmann classification), lymphatic invasion, tumor stage (22), and a history of preoperative chemotherapy or radiotherapy were evaluated by reviewing medical charts and pathology records. Those who had undergone preoperative chemotherapy or radiotherapy were excluded. Glass slides were reviewed to determine histological types according to the World Health Organization (WHO) and Lauren classifications.

For the analysis of promoter methylation, cases fulfilling the following requirements were selected: i) presence of adenocarcinoma occupying more than total area of $50 \mathrm{~mm}^{2}$ at both the primary and metastatic lymph node sites; ii) the presence of viable tumor cells occupying $>60 \%$ of each tumor focus; and iii) the absence of tumor-obscuring inflammation.
Finally, a total of 74 cases were selected and these 74 cases constituted the study population. The mean age of these 74 patients was 57.7 years and the male to female ratio was approximately 2.3:1. In terms of tumor stage, there was one case of stage I, 15 cases of stage II, 25 of stage III, and 33 of stage IV. By Lauren classification, 44 cases were of the intestinal type, 28 cases were of the diffuse type, and 2 cases were of the mixed type.

Clinical outcomes were followed from date of surgery till death or December 31, 2004, which resulted in a mean follow-up of 35 months (range 1-108 months). Cases lost to follow-up and those that died of a cause other than gastric cancer were censored during the survival rate analysis.

DNA extraction. The DNA was extracted from four tissue paraffin-blocks of: i) primary gastric cancers; ii) matched lymph node metastases; iii) non-neoplastic gastric mucosa; and iv) uninvolved lymph nodes. Targeted areas were labeled with a marking pen on H\&E-stained slides. Paraffin-blocks were sectioned at $10 \mu \mathrm{m}$, and sections were de-paraffinized and re-hydrated by xylene and alcohol. Prepared $50 \mathrm{~mm}^{2}$ areas, corresponding with regions labeled on H\&E-stained slides, were excised by scalpel blade taking care to prevent contamination. These tissues were then suspended in $0.5 \%$ Tween-20 buffer, heated at $90^{\circ} \mathrm{C}$ for $10 \mathrm{~min}$, and digested with proteinase $\mathrm{K}$ at $55^{\circ} \mathrm{C}$ for 90 min with gentle agitation. Digested samples were reacted with $2.5 \%$ Chelex 100 at $99^{\circ} \mathrm{C}$ for $10 \mathrm{~min}$ and centrifuged at $15,000 \mathrm{rpm}$ for $5 \mathrm{~min}$. Supernatants were stored at $4^{\circ} \mathrm{C}$ until required.

Bisulfite modification. Aliquots of $2.5 \mu \mathrm{g}$ of DNA with $10 \mu \mathrm{g}$ of salmon sperm DNA as a carrier, were heated at $99^{\circ} \mathrm{C}$ for $5 \mathrm{~min}$, and denatured in $0.3 \mathrm{~N} \mathrm{NaOH}$ at $37^{\circ} \mathrm{C}$ for $15 \mathrm{~min}$. To these denatured DNAs were added $2.5 \mathrm{M}$ sodium metabisulfite and $125 \mathrm{mM}$ hydroquinone ( $\mathrm{pH}$ 5.0), and samples were then incubated at $55^{\circ} \mathrm{C}$ for $16 \mathrm{~h}$ in the dark. Samples were then desalted using the Wizard DNA Clean-Up System (Promega, Madison, WI, USA), and desulfonated in $0.3 \mathrm{~N}$ $\mathrm{NaOH}$ at $37^{\circ} \mathrm{C}$ for $15 \mathrm{~min}$. The modified DNAs were then precipitated with ammonium acetate and cold alcohol and centrifuged at 15,000 rpm for 20 min keeping them under $4^{\circ} \mathrm{C}$. Pellets so obtained were dissolved in $20 \mu \mathrm{l}$ of distilled water and stored at $4^{\circ} \mathrm{C}$ until use.

Methylation-specific polymerase chain reaction (MSP). Reaction mixtures consisted of $5 \mu 1$ of Premix Ex Taq ${ }^{\mathrm{TM}}$ (Takara, Kyoto, Japan), each 5 pmol of forward and of reverse primers of both methylated and unmethylated alleles, $30 \sim 50 \mathrm{ng}$ of modified DNA template and $5 \mu \mathrm{l}$ of distilled water. PCR was hot-started at $95^{\circ} \mathrm{C}$ for $5 \mathrm{~min}$, and this was followed by 35 or 40 cycles of denaturation at $95^{\circ} \mathrm{C}$ for $30 \mathrm{sec}$, annealing for $30 \mathrm{sec}$, and extension at $72^{\circ} \mathrm{C}$ for $1 \mathrm{~min}$. A final 10 -min extension at $72^{\circ} \mathrm{C}$ completed each PCR. Annealing temperatures and cycle numbers were individually optimized for each of the primer sets by identifying an annealing temperature that produced only one specific band and the minimal cycle number that produced PCR products (Table I). The amplifications were carried out in ABI 2720 Thermal Cycler (Perkin-Elmer, CA, USA). After amplification, each PCR product was electrophoresed in $2.5 \%$ agarose gel and 
Table I. MSP primer sets and experimental conditions.

\begin{tabular}{|c|c|c|c|c|c|}
\hline Gene & Forward primer & Reverse primer & $\mathrm{Ta}^{\mathrm{a}}$ & $\mathrm{Cy}^{\mathrm{b}}$ & $\operatorname{Ref}^{\mathrm{c}}$ \\
\hline \multirow[t]{2}{*}{$A D A M 23$} & M GGGCGTACGTTCGTTTC & CAACGACTACGAAAACTACCG & 60 & 35 & $(30)$ \\
\hline & U GGGGTGGGGGTGTATGTTT & ACACAACCACTTCAACAACTACA & 60 & 35 & \\
\hline \multirow[t]{2}{*}{$\mathrm{CDHI}$} & M TTAGGTTAGAGGGTTATCGCGT & TAACTAAAAATTCACCTACCGAC & 60 & 40 & (13) \\
\hline & U TAATTTTAGGTTAGAGGGTTATTGT & CACAACCAATCAACAACACA & 60 & 35 & \\
\hline \multirow[t]{2}{*}{ FHIT } & M TTGGGGCGCGGGTTTGGGTTTTTACGC & CGTAAACGACGCCGACCCCACTA & 68 & 40 & $(20)$ \\
\hline & U TTGGGGTGTGGGTTTGGGTTTTTATG & CATAAACAACACCAACCCCACTA & 66 & 40 & \\
\hline \multirow[t]{2}{*}{$F L N C$} & M GAGAGAGAGTTAGAGAGCGGTCGAGC & GACCACGAAACTCGCTACGCTACG & 66 & 35 & $(27)$ \\
\hline & U GAGAGAGAGTTAGAGAGTGGTTGAGT & AАCCACAAAACTCACTACACTACA & 60 & 35 & \\
\hline \multirow[t]{2}{*}{ GSTP1 } & M TTCGGGGTGTAGCGCTCGTC & GCCCCAATACTAAATCACGACG & 62 & 40 & $(18)$ \\
\hline & U GATGTTTGGGGTGTAGTGGTTGTT & CСАССССААТАСТАААТСАСАACA & 60 & 40 & \\
\hline \multirow[t]{2}{*}{ ITGA4 } & M TAGAGTTATTTCGCGTTTTGCG & CTTCGAATACTCGCGCTACTT & 60 & 35 & $(17)$ \\
\hline & U GTTTAGAGTTATTTTGTGTTTTGTG & AАAАCTTCAАATACTCACACTACT & 60 & 35 & \\
\hline \multirow[t]{2}{*}{$L O X$} & M GAATAAATAGTTGAGGGGCGGTC & GCGACAATCCCGAAAAACG & 64 & 35 & $(15)$ \\
\hline & U TGTGAATAAATAGTTGAGGGGTGGTT & CAACACAACAATCCCAAAAAACA & 64 & 35 & \\
\hline \multirow[t]{2}{*}{$R U N X 3$} & M TTACGAGGGGCGGTCGTACGCGGG & AAAACGACCGACGCGAACGCCTCC & 68 & 35 & $(16)$ \\
\hline & U TTATGAGGGGTGGTTGTATGTGGG & AАAACAACCAACACAAACACCTCC & 68 & 40 & \\
\hline \multirow[t]{2}{*}{ THBS1 } & M TGCGAGCGTTTTTTTAAAAGC & TAAACTCGCAAACCAACTCG & 60 & 35 & (13) \\
\hline & U GTTTGGTTGTTGTTTATTGGTTG & ССТАААСТСАСАААССААСТСА & 60 & 35 & \\
\hline \multirow[t]{2}{*}{ TIMP3 } & M CGTTTCGTTATTTTTTGTTTTCGGTTTC & CCGAAAACCCCGCCTCG & 59 & 35 & (19) \\
\hline & U TTTTGTTTTGTTATTTTTTGTTTTTGGTTTT & CССССАAАAАССССАССТСА & 59 & 35 & \\
\hline \multirow[t]{2}{*}{ UCHL1 } & M GGTTCGGTCGTATTATTTCGC & ACTACATCTTCGCGAAACGCCCG & 62 & 35 & $(21)$ \\
\hline & U GGTTTGGTTGTATTATTTTGT & ACTACATCTTCACAAAACACCCA & 58 & 40 & \\
\hline
\end{tabular}

${ }^{\mathrm{a} A n n e a l i n g ~ t e m p e r a t u r e s ~}\left({ }^{\circ} \mathrm{C}\right) ;{ }^{b}$ numbers of cycles; ${ }^{\mathrm{c}}$ reference numbers.

visualized by ethidium bromide staining using ultraviolet light. The integrity and completeness of bisulfite conversions of modified DNAs were estimated using unmethylated GSTP1 gene because GSTP1 was rarely methylated in the present series. A sample was considered to have been methylated when an unequivocal specific band of a predicted size was detected in the reaction performed with methylated primer sets. Samples showing an equivocal band were re-subjected to MSP and those showing a specific band consistently were considered to have been methylated. SssI methylase-treated DNA or DNA from gastric cancer cell lines with known methylation status for each gene were used as positive controls. The distilled water without template was used as a negative control.

Statistical analyses. The differences in DNA methylation frequencies between primary and metastatic gastric carcinoma were estimated using NcMemar's test. The differences between numbers of methylated genes in primary and metastatic carcinomas were estimated using Wilcoxon's signed rank test. The $\chi^{2}$ test or Fisher's exact test (two-sided) were used to determine the significance of associations between the DNA methylation frequencies and clinicopathologic factors. Multivariate logistic regression analysis was used to confirm the presence of an independent significant association between the DNA methylations of multiple genes and clinicopathologic factors. Survival curves were estimated using the Kaplan-Meier product-limit method and the significance of differences between the survival curves were determined using the log-rank test. Multivariate analysis was performed using Cox's proportional hazards model. Results were considered to be statistically significant when the p-value was $<0.05$. All statistical analyses were conducted using SPSS ver. 12.0 (SPSS, Chicago, IL).

\section{Results}

Frequency of DNA methylation. Representative MSP results for 11 genes are shown in Fig. 1, and all results are shown in Fig. 2 and Table II. The frequencies of DNA methylation of the 11 genes in primary gastric carcinomas ranged from 1 case $(1.4 \%, G S T P 1)$ to 54 cases $(73.0 \%, I T G A 4)$, and the 


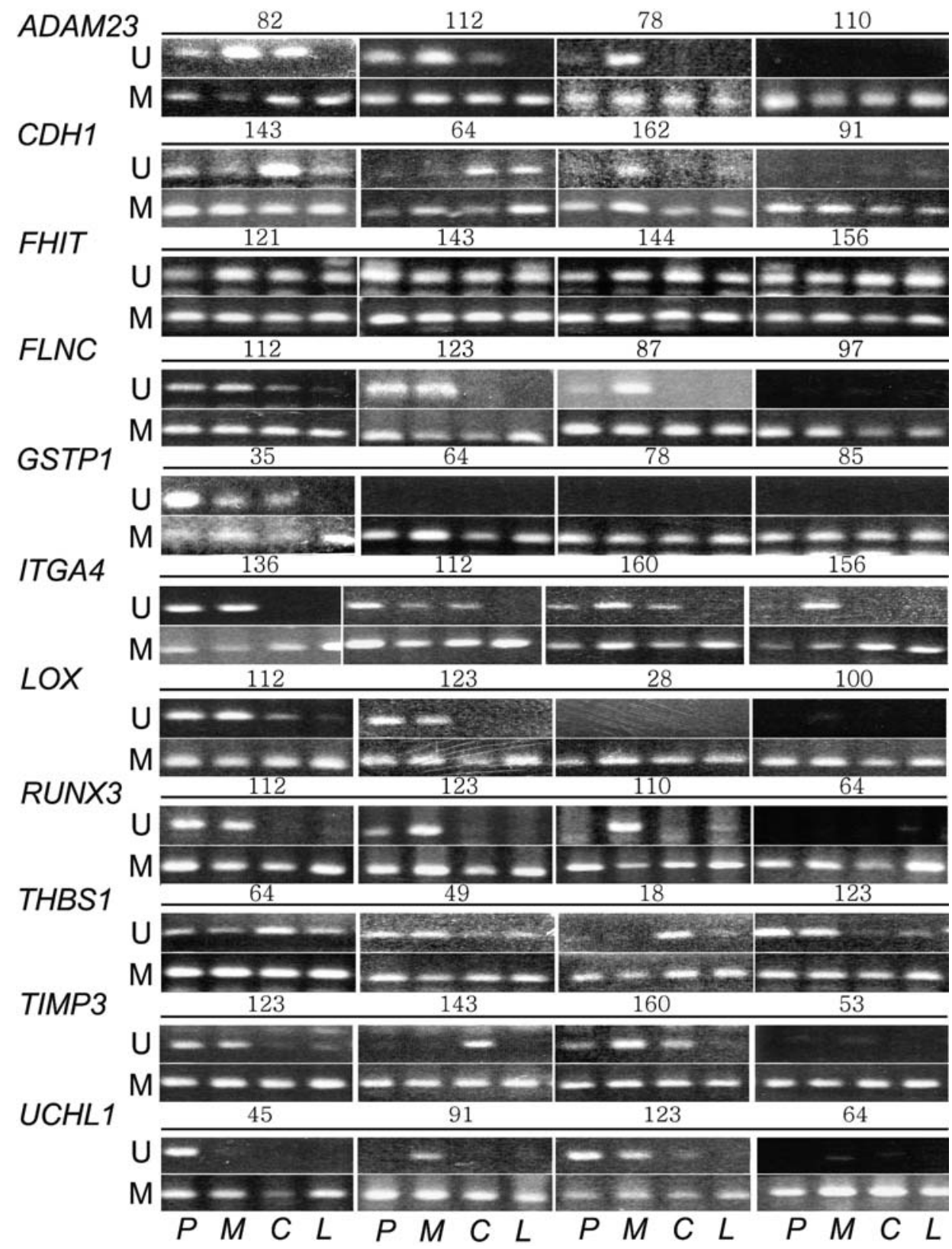

Figure 1. Representative MSP results of 11 genes in primary $(P)$ and metastatic $(M)$ gastric carcinomas and in corresponding non-neoplastic mucosal $(C)$, and uninvolved lymph node tissues $(L)$. Four methylated (M) bands and four unmethylated (U) bands are demonstrated for each case. The four bands represent results of $P, M, C$ and $L$ samples. Case numbers are shown at the top.

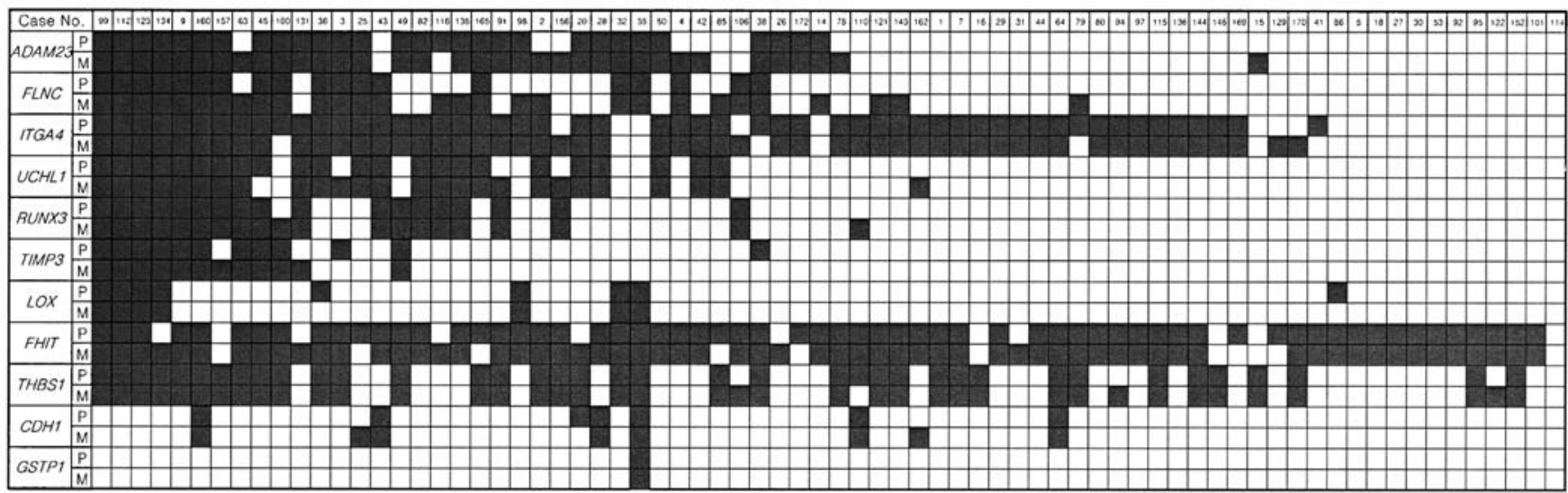

Figure 2. MSP results of individual samples. Empty squares (๑) represent the absence of a methylated allele, and filled squares ( $\mathbf{(})$ the presence of a methylated allele. No, number; P, primary gastric carcinoma; M, metastatic gastric carcinoma. 
Table II. Frequency of DNA methylation in primary and metastatic gastric carcinomas, and in corresponding non-neoplastic mucosa and uninvolved lymph node tissues.

\begin{tabular}{|c|c|c|c|c|c|}
\hline Gene & $\begin{array}{l}\text { Primary gastric } \\
\text { carcinoma } \\
(n=74)(\%)\end{array}$ & $\begin{array}{c}\text { Metastatic gastric } \\
\text { carcinoma } \\
(\mathrm{n}=74)(\%)\end{array}$ & $\begin{array}{c}\text { Non-neoplastic } \\
\text { mucosa } \\
(n=63)(\%)\end{array}$ & $\begin{array}{c}\text { Uninvolved lymph } \\
\text { nodes } \\
(\mathrm{n}=46)(\%)\end{array}$ & $\mathrm{p}$-value $\mathrm{a}^{\mathrm{a}}$ \\
\hline$A D A M 23$ & $29(39.2)$ & $35(47.3)$ & $6(9.5)$ & $2(4.3)$ & $<0.001$ \\
\hline $\mathrm{CDH}$ & $7(9.5)$ & $8(10.8)$ & $8(12.7)$ & $11(23.9)$ & 0.5 \\
\hline FHIT & $63(85.1)$ & $63(85.1)$ & $53(84.1)$ & $43(93.5)$ & 1.0 \\
\hline FLNC & $19(25.7)$ & $28(37.8)$ & $0(0)$ & $1(2.2)$ & $<0.001$ \\
\hline GSTP1 & $1(1.4)$ & $1(1.4)$ & $0(0)$ & $0(0)$ & 1.0 \\
\hline ITGA4 & $54(73.0)$ & $55(74.3)$ & $9(14.3)$ & $2(4.3)$ & $<0.001$ \\
\hline$L O X$ & $9(12.2)$ & $7(9.5)$ & $1(1.6)$ & $0(0)$ & 0.008 \\
\hline$R U N X 3$ & $18(24.3)$ & $20(27.0)$ & $2(3.2)$ & $0(0)$ & $<0.001$ \\
\hline THBSI & $38(51.4)$ & $40(54.1)$ & $32(50.8)$ & $27(58.7)$ & 1.0 \\
\hline TIMP3 & $12(16.2)$ & $12(16.2)$ & $3(4.8)$ & $0(0)$ & 0.039 \\
\hline UCHL1 & $23(31.1)$ & $26(35.1)$ & $5(7.9)$ & $1(2.2)$ & $<0.001$ \\
\hline $\begin{array}{l}\text { Average number of } \\
\text { methylated genes }\end{array}$ & $2.2^{\mathrm{b}}$ & $2.5^{\mathrm{b}}$ & $0.3^{\mathrm{c}}$ & $0.1^{\mathrm{c}}$ & $\begin{array}{l}0.004^{\mathrm{b}} \\
0.011^{\mathrm{c}}\end{array}$ \\
\hline
\end{tabular}

${ }^{\text {a}}$ Significances of differences in promoter methylation between primary gastric carcinoma and non-neoplastic mucosa by McNemar's test. ${ }^{\mathrm{b}, \mathrm{c}} \mathrm{p}$-value by Wilcoxon's signed rank test.

Table III. Changes in the methylation status from primary to metastatic gastric carcinomas.

\begin{tabular}{lccccc}
\hline & \multicolumn{3}{c}{ Changes in methylation status } & \\
\cline { 2 - 4 } & \multicolumn{2}{c}{$\begin{array}{l}\text { Primary gastric } \rightarrow \text { Metastatic gastric } \\
\text { carcinoma }\end{array}$} & \multicolumn{2}{c}{ p-value } \\
& carcinoma & \\
\cline { 2 - 4 } Gene & $\mathrm{U}^{\mathrm{a}} \rightarrow \mathrm{U}$ & $\mathrm{U} \rightarrow \mathrm{M}^{\mathrm{b}}$ & $\mathrm{M} \rightarrow \mathrm{U}$ & $\mathrm{M} \rightarrow \mathrm{M}$ & \\
\hline ADAM23 & 38 & 7 & 1 & 28 & 0.07 \\
FLNC & 46 & 9 & 0 & 19 & 0.004 \\
ITGA4 & 16 & 4 & 3 & 51 & 1.0 \\
LOX & 65 & 0 & 2 & 7 & 0.5 \\
RUNX3 & 54 & 2 & 0 & 18 & 0.5 \\
TIMP3 & 60 & 2 & 2 & 10 & 1.0 \\
UCHL1 & 47 & 4 & 1 & 22 & 0.375 \\
\hline
\end{tabular}

${ }^{a}$ Unmethylated; ${ }^{b}$ methylated; ${ }^{c}$-value by McNemar's test.

frequencies in metastatic gastric carcinomas were somewhat different. Genes were divided into two groups based on patterns of DNA methylation frequency in corresponding non-neoplastic mucosal and uninvolved lymph node tissues. One group showed a 'cancer-specific pattern' in which the DNA methylation was observed exclusively in tumor tissues and rarely in non-neoplastic mucosa or uninvolved lymph node tissues. The other group showed a 'cancer-unrelated pattern' in which methylation frequencies in non-neoplastic mucosa or uninvolved lymph node tissues were comparable to those in tumor tissues. The genes that showed a 'cancerspecific pattern' were ADAM23, FLNC, ITGA4, LOX, RUNX3, UCHL1, and TIMP3, whereas CDH1, FHIT, and THBS1 showed a 'cancer-unrelated pattern' (Table II). GSTP1 methylation appeared to be 'cancer-specific' but its frequency was extremely low. Consequently, only the seven genes showing a 'cancer-specific' pattern of DNA methylation were selected for further analysis.

Comparison of DNA methylation frequencies in primary and metastatic gastric carcinomas. Changes in the methylation status of the seven genes selected above (ADAM23, FLNC, ITGA4, LOX, RUNX3, UCHL1, and TIMP3) are listed in Table III. Of these, ADAM23 and FLNC tended to be more frequently methylated in metastatic gastric carcinomas, and this difference in FLNC methylation was significant $(\mathrm{p}=0.004)$. The remaining five genes also tended to show a higher frequency of methylation in metastatic gastric carcinomas. The majority (64 of 74 cases, $86.5 \%$ ) of gastric carcinomas showed methylation of at least one of these 7 genes in either a primary or metastatic site. The average number of genes methylated in the 74 cases increased from 2.2 for primary gastric carcinomas to 2.5 for metastatic gastric carcinomas and this difference was statistically significant $(\mathrm{p}=0.004)$.

Association between the frequency of DNA methylation and clinicopathologic factors. Promoter methylations of FLNC and TIMP3 were found to be associated with a female gender ( $\mathrm{p}=0.007$ and $\mathrm{p}=0.03$, respectively). $R U N X 3$ methylation was found to be associated with an advanced $\mathrm{T}$ class $(\mathrm{p}=0.028)$ 
Table IV. Associations between the high-methylation group and clinicopathological factors in gastric carcinoma.

\begin{tabular}{|c|c|c|c|c|c|}
\hline \multirow[t]{2}{*}{ Clinicopathological factors } & \multicolumn{2}{|c|}{ Methylation group } & \multirow[t]{2}{*}{ p-value ${ }^{a}$} & \multirow{2}{*}{$\frac{\text { Logistic regression }}{\text { Odds ratio }(95 \% \mathrm{CI})}$} & \multirow[t]{2}{*}{$\mathrm{p}$-value } \\
\hline & Low $(\%)$ & High (\%) & & & \\
\hline Median survival (months) & 17 & 8 & $0.299^{c}$ & & \\
\hline Age & & & 0.917 & - & - \\
\hline$<65$ & $34(61.8)$ & $21(38.2)$ & & & \\
\hline$\geq 65$ & $12(63.2)$ & $7(76.8)$ & & & \\
\hline Gender & & & 0.031 & & 0.030 \\
\hline Male & $37(69.8)$ & $16(30.2)$ & & 1.00 & \\
\hline Female & $9(42.9)$ & $12(57.1)$ & & $3.655(1.133-11.791)$ & \\
\hline Lauren classification & & & 0.022 & & 0.014 \\
\hline Intestinal & $33(75.0)$ & $11(25.0)$ & & 1.00 & \\
\hline Diffuse & $12(42.9)$ & $16(57.1)$ & & $3.957(1.323-11.840)$ & \\
\hline Mixed & $0(0)$ & $2(100)$ & & & \\
\hline Lymphatic invasion & & & 0.723 & - & - \\
\hline Absent & $20(64.5)$ & $11(35.5)$ & & & \\
\hline Present & $26(60.5)$ & $17(39.5)$ & & & \\
\hline Vascular invasion & & & 0.913 & - & - \\
\hline Absent & $39(61.9)$ & $24(38.1)$ & & & \\
\hline Present & $7(63.6)$ & $4(36.4)$ & & & \\
\hline $\mathrm{T}$ class $^{\mathrm{d}}$ & & & 0.231 & - & - \\
\hline $\mathrm{T} 1+\mathrm{T} 2$ & $23(70.0)$ & $10(30.0)$ & & & \\
\hline $\mathrm{T} 3+\mathrm{T} 4$ & $23(56.1)$ & $18(43.9)$ & & & \\
\hline $\mathrm{N}$ class $^{\mathrm{d}}$ & & & 0.030 & & 0.172 \\
\hline $\mathrm{N} 1+\mathrm{N} 2$ & $30(73.2)$ & $11(26.8)$ & & 1.00 & \\
\hline N3 & $16(48.5)$ & $17(51.5)$ & & $2.095(0.725-6.056)$ & \\
\hline Distant metastasis & & & 0.583 & - & - \\
\hline Absent & $39(60.9)$ & $25(39.1)$ & & & \\
\hline Present & $7(70.0)$ & $3(30.0)$ & & & \\
\hline pTNM stage $^{d}$ & & & 0.030 & & 0.172 \\
\hline $\mathrm{I}+\mathrm{II}+\mathrm{III}$ & $30(73.2)$ & $11(26.8)$ & & 1.00 & \\
\hline IV & $16(48.5)$ & $17(51.5)$ & & $2.095(0.725-6.056)$ & \\
\hline
\end{tabular}

${ }^{\mathrm{a}} \mathrm{p}$-value by the $\chi^{2}$ test. ${ }^{\mathrm{b}} \mathrm{p}$-value corrected by multivariate logistic regression. ${ }^{\mathrm{c}} \mathrm{p}$-value by the log-rank test. ${ }^{\mathrm{d}}$ Staging according to the AJCC Cancer Staging Manual (6th edition).

and TIMP3 methylation with an advanced pTNM stage $(p=0.02)$. However, no relation was found between the methylation status of any of 7 genes and prognosis.

Since methylation of multiple genes has been shown to be associated with a poor prognosis in esophageal adenocarcinoma (23) and bladder cancer (24), we investigated the association between the number of genes methylated in primary tumors and clinicopathological factors including prognosis. To divide cases into two groups according to the number of methylated genes in primary tumors, we arbitrarily divided cases into high-methylation (cases in which three or more genes were methylated in their primary sites) and low-methylation (cases in which two or fewer genes were methylated in their primary sites) groups because the average number of methylated genes in primary tumor was 2.2 (15). The high-methylation group was found to contain a greater number of female patients $(\mathrm{p}=0.03)$ and diffuse type tumors $(\mathrm{p}=0.02)$, and to be associated with an advanced $\mathrm{N}$ class and pTNM stage $(\mathrm{p}=0.03)$. However, multivariate logistic regression analysis showed that the $\mathrm{N}$ class and pTNM stage were not associated with high-methylation group. Median survival of high-methylation group tended to be shorter than that of low-methylation group (8 months vs. 17 months), but this difference was not significant (Table IV). 


\section{Discussion}

The present study demonstrated that DNA methylation profiles in metastatic gastric carcinoma were different from those in primary gastric carcinoma. Specifically, FLNC promoter was more frequently methylated in metastatic gastric carcinomas than in primary gastric carcinomas and the average number of methylated genes in metastatic gastric carcinomas was greater than that in primary gastric carcinomas. These findings indicate that the aberrant DNA methylation of FLNC may play a role in the metastasis of gastric carcinoma.

Differences between the methylation statuses of primary and metastatic tumors have been initially described in breast cancer. In one study (5), seven genes (MINT1, MINT2, MINT31, INK4A, CDH1, RAR- $\beta 2$ and THBS2) were analyzed in 6 breast cancers, and the methylation status of these genes in the metastatic sentinel lymph nodes was different from those in their primary counterparts. In another study (6), six genes (RASSF1A, APC, TWIST, CDH1, GSTP1 and RAR- $\beta 2$ ) were analyzed in 29 breast cancers, and promoter methylation of $\mathrm{CDH} 1$ was increased during sentinel lymph node metastasis. Consistent with these previous reports, we found that the DNA methylation profiles of metastatic gastric carcinomas differed from those of their primary counterparts. In addition, we found that FLNC promoter methylation was significantly higher in metastatic than in primary tumors.

$F L N C$, a member of the filamin family, has been known to organize actin polymerization in response to various signals (25). The aberrant methylation of FLNC promoter in gastric carcinoma was initially found using a genome scanning technique, namely, methylation-sensitive representational difference analysis (26). In the present study, the frequency of FLNC methylation in this report was $25.7 \%$ (19 of 74 cases) which is lower than that reported previously (41.3\%: 31 of 75 cases) (15). Functionally, FLNC is known to play a crucial role in muscle development and in the maintenance of muscle structural integrity (27). However, the biological role of $F L N C$ in other organs is poorly understood, and thus, speculation concerning the role of FLNC methylation in the metastasis of gastric cancer is premature.

$A D A M 23$ is a member of the ADAM family of disintegrins and metalloproteinase which are involved in control of growth factors, cytokines, membrane adhesion, and cell migration (28). The overexpressions of most ADAM family members usually accelerate tumorigenesis, whereas $A D A M 11$ and $A D A M 23$ inhibits tumorigenesis (29). In gastric carcinoma, the aberrant methylation of ADAM23 promoter has been reported to occur in $43.8 \%$ (7 of 16 cases) (30). In the present study, the frequency of ADAM23 methylation was comparable to that of the previous report and tended to increase during metastasis. However, this increase during metastasis was not statistically significant.

UCHL1, also called PGP9.5 (protein gene product 9.5), is a member of the ubiquitin carboxyl-terminal hydrolase family and is involved in the processing of ubiquitin precursors and of ubiquitinated proteins (31). In gastric carcinoma, promoter methylation of UCHL1 has been reported to occur in $48.4 \%$ ( 15 of 31 cases) and to be more frequent in diffuse type gastric carcinomas than in the intestinal type (32). Consistent with this previous report, we also observed that UCHL1 methylation tended to be more frequent in diffuse type gastric carcinoma than in the intestinal type ( $\mathrm{p}=0.057$, data not shown).

$R U N X 3$, a runt-related transcription factor, is known to have a tumor-suppressor activity and to be silenced in gastric carcinoma either by hemizygous deletion or by promoter hypermethylation (16). In one study, RUNX3 promoter methylation was detected in $75 \%$ of primary gastric carcinomas $(n=22)$ and in $100 \%$ of cells from malignant ascites (7). However, in contrast to this previous report, in the present study, $R U N X 3$ methylation was identified in $24.3 \%$ of primary gastric carcinomas and was not found to be increased in metastases. These differences may have been caused by selection bias in the previous report, in which all patients had peritoneal dissemination. In addition, it is also possible that $R U N X 3$ methylation plays a selective role in this process.

Frequencies of the methylations of the 11 genes in corresponding non-neoplastic mucosa of the present series were similar to those reported previously $(7,13,15,32)$, although the overall frequencies of $C D H 1$ and TIMP3 methylation were lower than those reported previously. These findings and our findings concerning methylation frequencies in uninvolved lymph nodes, which have not been reported yet, show that CDH1, FHIT and THBS1 are methylated in a cancer-unrelated fashion. Furthermore, this finding is supported by previous reports which concluded that $C D H 1, T I M P 3$ and THBS1 show aging-related methylation $(14,33)$. However, it should be added that in the present study the methylation pattern of TIMP3 was found to be cancer-specific, which disagrees with the findings of a previous report (14). In addition, in the present study, the extensive methylation of the FHIT gene in non-neoplastic gastric mucosa and uninvolved lymph nodes is reported for the first time.

The reason why genes showing cancer-specific methylation (ADAM23, FLNC, ITGA4, LOX, RUNX3, TIMP3 and $U C H L 1$ ) were occasionally methylated in non-neoplastic mucosa and uninvolved lymph nodes is unclear. Since most of non-neoplastic mucosal tissues in our cases showed either Helicobacter pylori infection or intestinal metaplasia (data not shown), the occasional methylation of these genes in non-neoplastic mucosa cannot be explained by Helicobacter pylori infection or intestinal metaplasia. Instead, we would be more inclined to believe that this pattern of methylation in non-neoplastic mucosa reflects ongoing carcinogenesis at the molecular level in histologically non-neoplastic mucosa. DNA methylation in uninvolved lymph nodes is also intriguing, although it may have possibly resulted from contaminating tumor cells which could be present in $10 \mu \mathrm{m}$ sections used for DNA extraction without being detected in $\mathrm{H} \& \mathrm{E}$-stained slides.

The association of high-methylation group with advanced $\mathrm{N}$ class and pTNM stage found in the present study is supported by a previous report in which DNA methylation was associated with tumor progression in gastric cancer (15). Furthermore, in the present study, the average number of genes methylated was greater in metastatic tumors than in primary tumors. These findings suggest that the methylations of multiple genes might be involved in metastasis. However, 
multivariate logistic regression analysis showed that only the female gender and diffuse type tumor by Lauren classification were independently associated with high-methylation group. It was of interest to find that an independent association of high-methylation group with diffuse type tumor, not with $\mathrm{N}$ class or pTNM stage, which suggests that the more frequent methylation in diffuse type tumors is attributable to an intrinsic property of these tumors rather than to their association with an advanced stage. An analysis of the methylation status of a large number of genes in an extended series of gastric cancer would probably shed additional light on this issue.

Because the methylation of the 11 genes examined in this study has been reported to be correlated with loss of expression of their target mRNAs, the losses of the specific biological functions of these genes may have contributed to metastasis. However, this may not be the case because FLNC methylation, which was found to be increased in metastatic tumors, was not found to be associated with tumor progression, and conversely, the methylations of RUNX3 and TIMP3, which were associated with an advanced T class or pTNM stage, were not increased in metastatic tumors. Thus, it seems more reasonable that accumulation of DNA methylation may be caused by long-standing proliferation during tumor progression, given that increased methylation of multiple genes has been reported to be associated with hepatic cirrhosis (34) and with ulcerative colitis (35) where long-standing inflammation and proliferation also occur.

Although the prognostic significance of the methylation of individual genes or multiple genes were not established in the present study, the high-methylation group tended to show a poorer prognosis. We suggest that an analysis of a larger number of samples is necessary to determine the effects of promoter methylation of multiple genes on prognosis.

One limitation of our study is that the 11 genes investigated are unlikely to be representative of global methylation profiles. Ideally, high-throughput global DNA methylation profiling techniques (36) should be used to reveal the real 'methylation signatures' of primary gastric carcinomas and their lymph node metastases. However, these high-throughput techniques require well-preserved fresh tissues which were not available to us. Nevertheless, despite this limitation, we did find that the FLNC promoter is more frequently methylated in metastatic gastric carcinoma than in its primary counterpart.

Based on the results mentioned above, it is evident that some portion of metastatic gastric carcinomas consist of various tumor cell clones that differ epigenetically from their primary counterparts. These differences may result from the generation of heterogeneous clones with different methylation profiles during primary tumor progression and their subsequent clonal selection during metastasis. The precise biological meanings of the DNA methylation differences found between primary and metastatic gastric carcinomas require further investigation.

In summary, the present study demonstrates that FLNC promoter is more frequently methylated in metastatic gastric carcinomas than in their primary counterparts, and that the number of methylated genes is greater in metastatic gastric carcinomas than in their primary counterparts. Although we failed to identify a clinical factor related to $F L N C$ methylation, we did find that multiple gene methylation was independently associated with the female gender and a diffuse type. These differences between the methylation profiles of primary and metastatic gastric carcinoma indicate that FLNC promoter methylation or those of multiple genes may be involved in the metastasis of gastric carcinoma. Consequently, we suggest that an investigation of metastatic tumors should be undertaken to characterize the methylation profile of node-positive gastric carcinoma, and that the heterogeneous methylation in primary and metastatic lesions should be considered when applying a new therapeutic strategy of modifying the methylated DNA.

\section{Acknowledgements}

This work was supported by the 21C Frontier Functional Human Genome Project of the Ministry of Education, Science, and Technology, Republic of Korea (\#FG08-11-03).

\section{References}

1. Oue N, Hamai Y, Mitani Y, Matsumura S, Oshimo Y, Aung PP, Kuraoka K, Nakayama $\mathrm{H}$ and Yasui W: Gene expression profile of gastric carcinoma: identification of genes and tags potentially involved in invasion, metastasis, and carcinogenesis by serial analysis of gene expression. Cancer Res 64: 2397-2405, 2004.

2. El-Rifai W, Frierson HF Jr, Harper JC, Powell SM and Knuutila S: Expression profiling of gastric adenocarcinoma using cDNA array. Int J Cancer 92: 832-838, 2001.

3. Hippo Y, Yashiro M, Ishii M, Taniguchi H, Tsutsumi S, Hirakawa K, Kodama T and Aburatani H: Differential gene expression profiles of scirrhous gastric cancer cells with high metastatic potential to peritoneum or lymph nodes. Cancer Res 61: 889-895, 2001

4. Hynes RO: Metastatic potential: generic predisposition of the primary tumor or rare, metastatic variants - or both? Cell 113: 821-823, 2003.

5. Cavalli LR, Urban CA, Dai D, de Assis S, Tavares DC, Rone JD, Bleggi-Torres LF, Lima RS, Cavalli IJ, Issa JP and Haddad BR: Genetic and epigenetic alterations in sentinel lymph nodes metastatic lesions compared to their corresponding primary breast tumors. Cancer Genet Cytogenet 146: 33-40, 2003.

6. Shinozaki M, Hoon DS, Giuliano AE, Hansen NM, Wang HJ, Turner R and Taback B: Distinct hypermethylation profile of primary breast cancer is associated with sentinel lymph node metastasis. Clin Cancer Res 11: 2156-2162, 2005.

7. Sakakura C, Hasegawa K, Miyagawa K, Nakashima S, Yoshikawa T, Kin S, Nakase Y, Yazumi S, Yamagishi H, Okanoue T, Chiba T and Hagiwara A: Possible involvement of RUNX3 silencing in the peritoneal metastases of gastric cancers. Clin Cancer Res 11: 6479-6488, 2005.

8. Zidan J, Dashkovsky I, Stayerman C, Basher W, Cozacov C and Hadary A: Comparison of HER-2 overexpression in primary breast cancer and metastatic sites and its effect on biological targeting therapy of metastatic disease. Br J Cancer 93: 552-556, 2005 .

9. Italiano A, Vandenbos FB, Otto J, Mouroux J, Fontaine D, Marcy PY, Cardot N, Thyss A and Pedeutour F: Comparison of the epidermal growth factor receptor gene and protein in primary non-small-cell-lung cancer and metastatic sites: implications for treatment with EGFR-inhibitors. Ann Oncol 17: 981-985, 2006.

10. Baylin SB, Herman JG, Graff JR, Vertino PM and Issa JP: Alterations in DNA methylation: a fundamental aspect of neoplasia. Adv Cancer Res 72: 141-196, 1998.

11. Crew KD and Neugut AI: Epidemiology of gastric cancer. World J Gastroenterol 12: 354-362, 2006.

12. Oue N, Sentani K, Yokozaki H, Kitadai Y, Ito R and Yasui W: Promoter methylation status of the DNA repair genes hMLH1 and MGMT in gastric carcinoma and metaplastic mucosa. Pathobiology 69: 143-149, 2001.

13. Kang GH, Lee S, Kim JS and Jung HY: Profile of aberrant $\mathrm{CpG}$ island methylation along the multistep pathway of gastric carcinogenesis. Lab Invest 83: 635-641, 2003. 
14. Kang GH, Lee HJ, Hwang KS, Lee S, Kim JH and Kim JS: Aberrant $\mathrm{CpG}$ island hypermethylation of chronic gastritis, in relation to aging, gender, intestinal metaplasia, and chronic inflammation. Am J Pathol 163: 1551-1556, 2003.

15. Oue N, Mitani Y, Motoshita J, Matsumura S, Yoshida K, Kuniyasu H, Nakayama $\mathrm{H}$ and Yasui W: Accumulation of DNA methylation is associated with tumor stage in gastric cancer. Cancer 106: 1250-1259, 2006.

16. Li QL, Ito K, Sakakura C, Fukamachi H, Inoue K, Chi XZ, Lee KY, Nomura S, Lee CW, Han SB, Kim HM, Kim WJ, Yamamoto $\mathrm{H}$, Yamashita $\mathrm{N}$, Yano $\mathrm{T}$, Ikeda $\mathrm{T}$, Itohara $\mathrm{S}$ Inazawa J, Abe T, Hagiwara A, Yamagishi H, Ooe A, Kaneda A, Sugimura T, Ushijima T, Bae SC and Ito Y: Causal relationship between the loss of RUNX3 expression and gastric cancer. Cell 109: 113-124, 2002.

17. Park J, Song SH, Kim TY, Choi MC, Jong HS, Lee JW, Kim NK, Kim WH and Bang YJ: Aberrant methylation of integrin alpha4 gene in human gastric cancer cells. Oncogene 23: 3474-3480, 2004.

18. Esteller M, Corn PG, Urena JM, Gabrielson E, Baylin SB and Herman JG: Inactivation of glutathione S-transferase P1 gene by promoter hypermethylation in human neoplasia. Cancer Res 58: 4515-4518, 1998.

19. Bachman KE, Herman JG, Corn PG, Merlo A, Costello JF, Cavenee WK, Baylin SB and Graff JR: Methylation-associated silencing of the tissue inhibitor of metalloproteinase-3 gene suggest a suppressor role in kidney, brain, and other human cancers. Cancer Res 59: 798-802, 1999.

20. Kuroki T, Trapasso F, Yendamuri S, Matsuyama A, Alder H, Mori $\mathrm{M}$ and Croce CM: Allele loss and promoter hypermethylation of VHL, RAR-beta, RASSF1A, and FHIT tumor suppressor genes on chromosome $3 p$ in esophageal squamous cell carcinoma. Cancer Res 63: 3724-3728, 2003.

21. Lee YM, Lee JY, Kim MJ, Bae HI, Park JY, Kim SG and Kim DS: Hypomethylation of the protein gene product 9.5 promoter region in gallbladder cancer and its relationship with clinicopathological features. Cancer Sci 97: 1205-1210, 2006.

22. American JCOC: AJCC Cancer Staging Manual (6th edition). Springer Science+Business Media Inc., New York, 2006.

23. Brock MV, Gou M, Akiyama Y, Muller A, Wu TT, Montgomery E, Deasel M, Germonpre P, Rubinson L, Heitmiller RF, Yang SC, Forastiere AA, Baylin SB and Herman JG: Prognostic importance of promoter hypermethylation of multiple genes in esophageal adenocarcinoma. Clin Cancer Res 9: 2912-2919, 2003.

24. Maruyama R, Toyooka S, Toyooka KO, Harada K, Virmani AK, Zochbauer-Muller S, Farinas AJ, Vakar-Lopez F, Minna JD, Sagalowsky A, Czerniak B and Gazdar AF: Aberrant promoter methylation profile of bladder cancer and its relationship to clinicopathological features. Cancer Res 61: 8659-8663, 2001.
25. Stossel TP, Condeelis J, Cooley L, Hartwig JH, Noegel A, Schleicher M and Shapiro SS: Filamins as integrators of cell mechanics and signalling. Nat Rev Mol Cell Biol 2: 138-145, 2001.

26. Kaneda A, Kaminishi M, Yanagihara K, Sugimura T and Ushijima T: Identification of silencing of nine genes in human gastric cancers. Cancer Res 62: 6645-6650, 2002.

27. Dalkilic I, Schienda J, Thompson TG and Kunkel LM: Loss of FilaminC (FLNc) results in severe defects in myogenesis and myotube structure. Mol Cell Biol 26: 6522-6534, 2006.

28. Seals DF and Courtneidge SA: The ADAMs family of metalloproteases: multidomain proteins with multiple functions. Genes Dev 17: 7-30, 2003.

29. Costa FF, Verbisck NV, Salim AC, Ierardi DF, Pires LC, Sasahara RM, Sogayar MC, Zanata SM, Mackay A, O'Hare M, Soares F, Simpson AJ and Camargo AA: Epigenetic silencing of the adhesion molecule ADAM23 is highly frequent in breast tumors. Oncogene 23: 1481-1488, 2004.

30. Takada H, Imoto I, Tsuda H, Nakanishi Y, Ichikura T, Mochizuki H, Mitsufuji S, Hosoda F, Hirohashi S, Ohki M and Inazawa J: ADAM23, a possible tumor suppressor gene, is frequently silenced in gastric cancers by homozygous deletion or aberrant promoter hypermethylation. Oncogene 24: 8051-8060, 2005.

31. Wilkinson KD, Lee KM, Deshpande S, Duerksen-Hughes P, Boss JM and Pohl J: The neuron-specific protein PGP 9.5 is a ubiquitin carboxyl-terminal hydrolase. Science 246: 670-673, 1989.

32. Yamashita K, Park HL, Kim MS, Osada M, Tokumaru Y, Inoue H, Mori M and Sidransky D: PGP9.5 methylation in diffuse-type gastric cancer. Cancer Res 66: 3921-3927, 2006.

33. Waki T, Tamura G, Sato M and Motoyama T: Age-related methylation of tumor suppressor and tumor-related genes: an analysis of autopsy samples. Oncogene 22: 4128-4133, 2003.

34. Shen L, Ahuja N, Shen Y, Habib NA, Toyota M, Rashid A and Issa JP: DNA methylation and environmental exposures in human hepatocellular carcinoma. J Natl Cancer Inst 94: 755-761, 2002.

35. Issa JP, Ahuja N, Toyota M, Bronner MP and Brentnall TA: Accelerated age-related $\mathrm{CpG}$ island methylation in ulcerative colitis. Cancer Res 61: 3573-3577, 2001.

36. Beck S and Rakyan VK: The methylome: approaches for global DNA methylation profiling. Trends Genet 24: 231-237, 2008. 